\title{
Sistem Informasi Absensi, Penggajian, dan Pinjaman Pegawai pada PT. X
}

\author{
Annisa Paramitha F. ${ }^{1}$, Ramdani Febrianto ${ }^{2}$ \\ ${ }^{1,2}$ Program Studi Sistem Informasi,Universitas Komputer Indonesia, Indonesia \\ e-mail: ${ }^{1}$ annisa@email.unikom.ac.id
}

\begin{abstract}
Abstrak
PT. $X$ merupakan perusahaan manufaktur, yang membuat mesin produksi serta part pendukungnya. PT X belum sepenuhnya memiliki sistem informasi untuk proses administrasi perusahaan, oleh karena itu terdapat kendala yang terjadi dikarenakan perusahaan belum menerapkan sistem informasi berbasis computer (CBIS). Permasalahan yang ada perusahaan dengan proses absensi, penggajian dan pinjaman pegawai. Perusahaan saat ini masih menggunakan Microsoft Excel sebagai alat bantu untuk kegiatan administrasi pegawai. Penggunaan MS. Excel tersebut cukup membantu, akan tapi masih terdapat kekurangan dalam proses pencatatan data dan pelaporan. Oleh karena itu perlu dirancang sebuah sistem yang terkoneksi dengan database sehingga kegiatan administrasi dapat terintegrasi dengan baik dan menghindari redudansi data. Pada penelitian ini, metode pengembangan sistem yang digunakan yaitu metode prototype sedangkan, metode pendekatan sistem yang digunakan adalah Object Oriented dengan alat bantu analisis dan perancangan menggunakan UML. Hasil dari penelitian ini berupa rancangan sistem informasi Absensi, penggajian dan pinjaman pegawai.
\end{abstract}

Kata Kunci:Sistem Informasi, Kepegawaian, UML

\begin{abstract}
PT. $X$ is a manufacturing company, which makes production machines and supporting parts. PT X does not yet fully have an information sistem for company administration processes, therefore some obstacles occur because the company has not implemented a computer-based information sistem (CBIS). The company has problems with attendance, payroll, and employee loan processes. The company is currently still using Microsoft Excel as a tool for employee administration activities. The use of MS. Excel is quite helpful, but there are still deficiencies in the process of recording data and reporting. Therefore, it is necessary to design a sistem that is connected to the database so that administrative activities can be well integrated and avoid data redundancy. In this study, the sistem development method used is the prototype method, while the sistems approach method used is ObjectOriented with analysis and design tools using UML. The results of this study are in the form of attendance information sistem design, payroll, and employee loans.
\end{abstract}

Keywords: Information Sistems, Human Resources, UML

\section{Pendahuluan}

PT. X merupakan perusahaan manufaktur pembuatan mesin produksi serta part pendukungnya. PT X belum sepenuhnya memiliki sistem informasi untuk proses administrasi perusahaan, oleh karena itu terdapat kendala yang terjadi dikarenakan perusahaan belum menerapkan sistem informasi berbasis computer (CBIS). Masalah yang 
diangkat pada penelitian ini adalah masalah yang terkait dengan proses absensi, penggajian dan pinjaman pegawai.

Perusahaan tersebut masih menggunakan Microsoft Excel sebagai alat bantu untuk kegiatan administrasi pegawai, penggunaan Microsoft Excel tersebut cukup membantu tapi masih terdapat kekurangan dalam penggunaannya. Proses penggajian pada perusahaan yang masih menggunakan aplikasi Microsoft Excel mengalami kendala dalam pembuatan slip gaji pegawai dikarenakan data yang ada Microsoft Excel tersebut belum terintegrasi sehingga dalam pembuatan slip gaji memerlukan waktu yang lama. Dengan penggunaan Microsoft Excel pun dapat terjadi redudansi data, dikarenakan file belum terintegrasi. Proses administrasi dan pencatatan dalam proses peminjaman pegawai dan pencairan belum terkelola dengan baik. Adanya kendala dalam perhitungan angsuran pegawai dan penggajian pegawai karena data atau file yang belum terintegrasi, sehingga sering kali terjadi kesalahan dalam proses perhitungan baik gaji maupun pinjaman pegawai. Dari masalah - masalah yang ada tersebut maka, perlu dirancang sebuah sistem informasi, yang mampu mengelola proses absensi, penggajian serta pinjaman pegawai. Dengan adanya sisten informasi yang terintegrasi dengan database, akan dapat memberikan solusi dari permasalahan yang ada pada perusahaan.

\section{KAJIAN PUSTAKA}

\subsection{Penelitian Terdahulu}

Pada penelitian ini, terdapat beberapa referensi sebagai acuan dalam melakukan penulisan. Penelitian pertama dengan judul "Sistem Informasi Kepegawaian di Dinas Perhubungan Kabupaten Garut". Penelitian tersebut membahas mengenai pengelolaan data kepegawaian, yaitu proses absensi, penggajian, dan kenaikan pangkat. [1]

Kemudian penelitian selanjutnya adalah "Rancang Bangun Sistem Informasi Kepegawaian (Studi Kasus : PT Dekatama Centra)". Penelitian ini membahas mengenai pengelolaan data absensi, perhitungan kehadiran pegawai, proses penggajian pegaawai, serta proses mutasi pegawai, kontrak kerja dan pinjaman pegawai. [2]

Penelitian selanjutnya yang terkait adalah "Sistem Informasi Penggajian di PT. Perkebunan Nusantara IV". Pembahasan pada penelitian ini meliputi, pengelolaan data pegawai serta pengelolaan data gaji pegawai. [3]

\subsection{Landasan Teori}

\subsubsection{Pengertian Data}

Data adalah deskripsi dari sesuatu dan kejadian yang kita hadapi (the description of things and events that we face). Definisi data lain adalah data merupakan kemyataan yang menggambarkan sesuatu kejadian - kejadian dan kesatuan nyata.[4]

\subsubsection{Pengertian Informasi}

Informasi diperoleh setelah data - data mentah diproses atau diolah. Menurut John Burch dan Gary Grudnitski, agar informasi yang dihasilkan lebih berharga, maka harus memenuhi kriteria sebagai berikut :

a. Informasi harus akurat, sehigga mendukung pihak manajemen dalam mengambil keputusan 
b. Informasi harus relevan, benar-benar terasa manfaatnya bagi yang membutuhkan

c. Informasi harus tepat waktu, sehingga tidak ada keterlambatan pada saat dibutuhkan. [4]

\subsubsection{Pengertian Sistem}

Sistem merupakan kumpulan dari beberapa bagian yang memiliki keterkaitan dan saling bekerja sama serta membentuk suatu kesatuan untuk mencapai suatu tujuan dari sistem tersebut. Maksud dari suatu sistem adalah untuk mencapai suatu tujuan dan sasaran dalam ruang lingkup yang sempit. Menurut Hall sistem adalah: " A sistem is a group of two or more interrelated components or subsistems that serve a common purpose".[5]

\subsubsection{Pengertian Sistem Informasi}

Menurut Jane P. Laudon sistem informasi adalah sekumpulan komponen yang saling terhubung, mengumpulkan, memproses, menyimpan, dan mendistribusikan informasi, dengan tujuan yang sama, untuk menunjang pengambilan keputusan dan pengawasan dalam suatu organisasi.[6]

\subsubsection{Pengertian Gaji}

Upah ialah suatu penerimaan kerja yang bertujuan untuk memberikan jaminan kelangsungan hidup yang layak bagi kemanusiaan dan produksi berdasarkan Undangundang dan Peraturan dan diberikan atas dasar suatu perjanjian kerja antara perusahaan dan pegawai. [7]

\section{Metode Penelitian}

Metode pendekatan sistem yang digunakan adalah Object Oriented dengan alat bantu analisis dan perancangan menggunakan UML,[8] diagram yang digunakan antara lain diagram usecase, diagram aktivitas, diagram sekuen, diagram kelas dan diagram deployment. Metode pengembangan sistem yang digunakan adalah Prototyping. [9] Metode ini adalah metode yang sangat umum digunakan dalam pengembangan sistem. Metode prototype ini digunakan dalam proses analisis sistem yan berjalan, kemudian pada proses perancangan program serta pada proses tahapan awal pengujian kepada user. Tahapan protype dapat dilihat pada gambar 1.

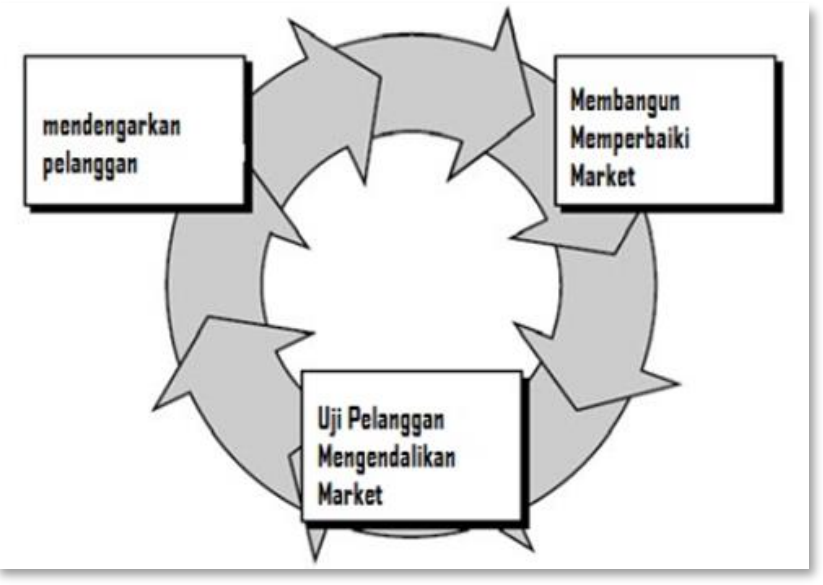

Gambar 1 Metode Pengembangan Sistem Prototype[6]

4. HASIL DAN PEMBAHASAN 
Dengan adanya hasil analisis yang dilakukan pada tahapan sebelumnya, dan rancangan sistem yang akan dibuat, dapat dilihat pada tabel 1.

Tabel 1 Evaluasi sistem yang berjalan

\begin{tabular}{|c|l|l|}
\hline No & \multicolumn{1}{|c|}{ Sistem yang Berjalan } & \multicolumn{1}{c|}{ Sistem yang diusulkan } \\
\hline 1. & $\begin{array}{l}\text { Proses pengolahan data penggajian } \\
\text { belum terkomputerisasi dengan baik } \\
\text { sehingga kesulitan dalam } \\
\text { pembuatan laporan penggajian }\end{array}$ & $\begin{array}{l}\text { Dirancang sebuah aplikasi untuk } \\
\text { pengolahan data penggajian. }\end{array}$ \\
\hline 2. & $\begin{array}{l}\text { Masih sering adanya kesalahan } \\
\text { perhitungan dalam pengolahan data } \\
\text { penggajian, yang berakibat pada } \\
\text { pembuatan laporan penggajian yang } \\
\text { tidak tepat waktu. }\end{array}$ & $\begin{array}{l}\text { Dirancangnya sebuah sistem } \\
\text { informasi yang dapat mempermudah } \\
\text { perhitungan gaji pegawai, sehingga } \\
\text { nantinya proses perhitungan menjadi } \\
\text { lebih cepat, tepat, dan akurat. }\end{array}$ \\
\hline 3. & $\begin{array}{l}\text { Proses pembuatan laporan } \\
\text { penggajian masih membutuhkan } \\
\text { waktu yang cukup lama karena file- } \\
\text { file yang dibutuhkan masih terpisah } \\
\text { dan belum terintegrasi kedalam } \\
\text { sebuah aplikasi sehingga data harus } \\
\text { dicocokan terlebih dahulu. }\end{array}$ & $\begin{array}{l}\text { Dengan adanya aplikasi ini, dapat } \\
\text { lebih mengefisienkan waktu dalam } \\
\text { pembuatan laporan. Sehingga laporan } \\
\text { penggajian dapat dibuat sesuai } \\
\text { dengan waktu yang telah ditetapkan. }\end{array}$ \\
\hline
\end{tabular}

Berikut adalah hasil dari perancangan sistem, berdasarkan hasil analisis sistem yang berjalan, penggambaran sistem yang diusulkan menggunakan Diagram Usecase.[10] Usecase yang diusulkan di PT. X dapat dilihat pada gambar 2. Aktor yang terlibat dalam system yang diusulkan antara lain pegawai, general manager, administration \& financial, dan direktur utama seperti tertera pada table 2. Adapun case yang diusulkan adalah Absensi, Penggajian, Angsuran, Kelola Laporan, dan Pinjaman seperti terlihat pada gambar 2 dan tabel 3.

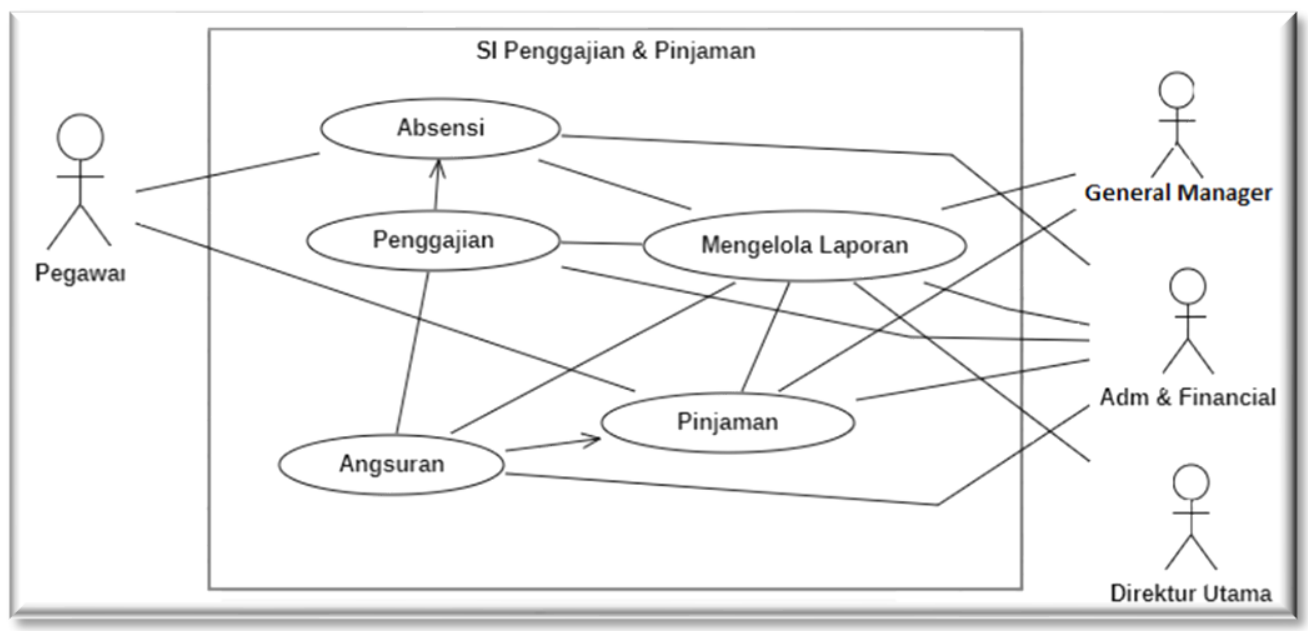

Gambar 2 Diagram Usecase yang diusulkan 
Tabel 2 Deskripsi Aktor

\begin{tabular}{|c|l|l|}
\hline No & \multicolumn{1}{|c|}{ Aktor } & \multicolumn{1}{c|}{ Deskripsi } \\
\hline 1 & Pegawai & $\begin{array}{l}\text { Orang yang melakukan absensi dan } \\
\text { mengajukan pinjaman }\end{array}$ \\
\hline 2 & General Manager & $\begin{array}{l}\text { Orang yang bertugas dan memiliki hak akses } \\
\text { untuk mengelola data pinjaman dan } \\
\text { memvalidasi laporan }\end{array}$ \\
\hline 3 & $\begin{array}{l}\text { Administrasi \& } \\
\text { Finansial }\end{array}$ & $\begin{array}{l}\text { Orang yang bertugas dan memiliki hak akses } \\
\text { untuk melakukan operasi pengelolaan data } \\
\text { absensi, penggajian dan laporan. }\end{array}$ \\
\hline 4 & Direktur Utama & Orang yang menerima laporan \\
\hline
\end{tabular}

Tabel 3 Deskripsi Usecase

\begin{tabular}{|c|l|l|}
\hline No & Use case & \multicolumn{1}{c|}{ Deskripsi } \\
\hline 1 & Absensi & $\begin{array}{l}\text { Proses dimana pegawai melakukan absensi dan di } \\
\text { rekap bulanan oleh administrasi \& finansial kedalam } \\
\text { aplikasi }\end{array}$ \\
\hline 2 & Pinjaman & $\begin{array}{l}\text { Proses dimana pegawai mengajukan pinjaman } \\
\text { kepada general manager dan diinputkan data } \\
\text { pinjaman kedalam aplikasi }\end{array}$ \\
\hline 3 & Angsuran & $\begin{array}{l}\text { Proses dimana administrasi \& finansial memasukan } \\
\text { data angsuran ke dalam aplikasi }\end{array}$ \\
\hline 4 & Penggajian & $\begin{array}{l}\text { Proses dimana administrasi \& finansial mengelola } \\
\text { data gaji pegawai }\end{array}$ \\
\hline 5 & Laporan & $\begin{array}{l}\text { Proses dimana administrasi \& finansial mengelola } \\
\text { laporan }\end{array}$ \\
\hline
\end{tabular}

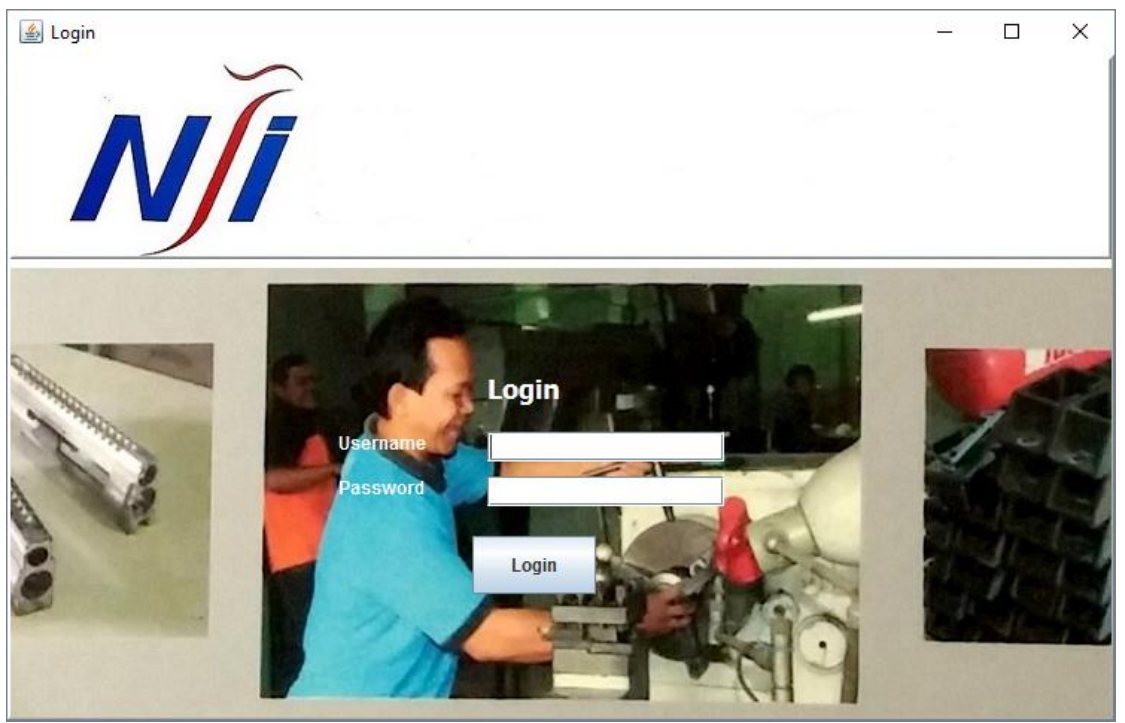

Gambar 3 Login Sistem Informasi Absensi, Penggajian, dan Pinjaman Pegawai pada PT. $\mathrm{X}$

Pada Gambar 3, adalah tampilan login untuk sistem informasi absensi, penggajian, dan pinjaman pegawai. Pada aplikasi ini, yang diberikan hak akses ialah General manager, 
Direktur Utama, Administration \& Finance, dan pegawai. Setiap aktor harus login terlebih dahulu sebelum dapat menggunakan system informasi ini. Penjelasan mengenai hak akses user dapat dilihat pada tabel 2 dan untuk penjelasan singkat mengenai sistem dapat dilihat pada tabel 3. Gambar 4 merupakan tampilan aplikasi dari data absen, sistem informasi yang telah dibuat. Data absen terdiri dari nomor absen, ID pegawai, nama pegawai, hari kerja, lembur (jam), lembur (hari), shift, uang makan, izin, sakit, alfa, cuti, terlambat, dan snack.

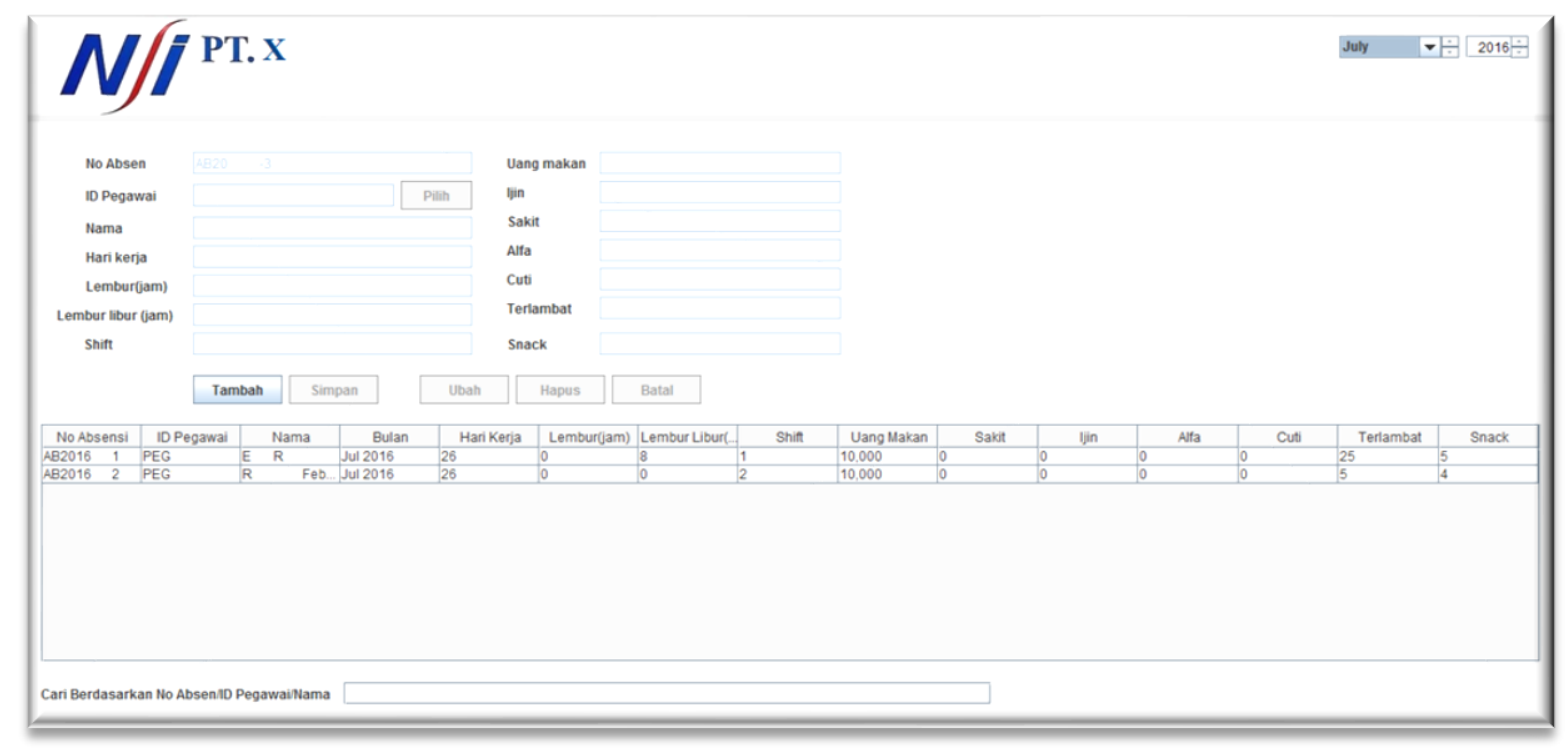

Gambar 4 Tampilan absen/kehadiran karyawan

\section{KESIMPULAN}

Dengan dibuatkan sistem informasi absesnsi, penggajian dan pinjaman dapat mempermudah proses pengelolaan data absensi, penggajian dan pinjaman pegawai. Dengan adannya sistem tersebut juga dapat mempermudah pembuatan laporan-laporan yang terkait. Sistem ini juga membantu pihak manajerial dalam pengambilan keputusan terkait dengan pinjaman pegawai.

\section{Daftar Pustaka}

[1] A. P. F dan R. S. Akbari, "Sistem Informasi Kepegawaian Di Dinas Perhubungan Kabupaten Garut," J. Teknol. dan Inf., vol. 5, no. 2, hal. 1-10, 2015, doi: 10.34010/JATI.V5I2.817.

[2] J. C. Wibawa dan F. Julianto, "Rancang Bangun Sistem Informasi Kepegawaian (Studi Kasus : PT Dekatama Centra)," J. Tek. Inform. dan Sist. Inf., vol. 2, no. 2, hal. 173-185, 2016, doi: 10.28932/jutisi.v2i2.455.

[3] A. Hamizan, M. Mayasari, R. Saputri, dan R. N. Pohan, "Sistem Informasi Penggajian di PT. Perkebunan Nusantara IV," J. Manaj. Inform., 2020, doi: 10.34010/jamika.v10i1.2656.

[4] Ladjamudin Al-Bahra, "Analisis Dan Desain Sistem Informasi," in Analisis Dan Desain Sistem Informasi, 2013.

[5] A. Kadir, “Konsep Dasar Sistem Informasi,” Konsep Dasar Sist. Inf., 2016. 
[6] R. A. Sukamto dan M. Shalahuddin, Rekayasa Perangkat Lunak (Terstruktur dan berbasis objek). 2016.

[7] "Sistem informasi absensi dan penggajian pegawai di cv. wiranty skripsi," hal. 2013, 2013.

[8] N. R. Radliya dan E. Hermawan, "Aplikasi Pendukung Kinerja Karyawan di Mitra Dinamika Konsultan,” J. Manaj. Inform., vol. 5, no. 2, hal. 81-95, 2015.

[9] T. Sutabri, Analisis Sistem Informasi, 1st ed. Bandung: Penerbit Informatika, 2012.

[10] Munawar, "Analisis Perancangan Sistem Berorientasi Objek dengan UML," Informatika Ban, 2018. 